BMJ Open

Respiratory

Research

\section{Association between prehospital vitamin $D$ status and incident acute respiratory failure in critically ill patients: a retrospective cohort study}

To cite: Thickett DR, Moromizato T, Litonjua AA, et al. Association between prehospital vitamin D status and incident acute respiratory failure in critically ill patients: a retrospective cohort study. BMJ Open Resp Res 2015;2: e000074. doi:10.1136/ bmjresp-2014-000074

- Additional material is available. To view please visit the journal (http://dx.doi.org/ 10.1136/bmjresp-2014000074)

Received 4 December 2014 Revised 29 April 2015 Accepted 21 May 2015

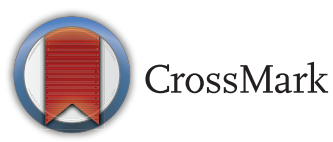

For numbered affiliations see end of article.

Correspondence to Dr Kenneth B Christopher; kbchristopher@partners.org

\section{ABSTRACT}

Objective: We hypothesise that low 25-hydroxyvitamin D (25(OH)D) levels before hospitalisation are associated with increased risk of acute respiratory failure.

Design: Retrospective cohort study.

Setting: Medical and Surgical Intensive care units of two Boston teaching hospitals.

Patients: 1985 critically ill adults admitted between 1998 and 2011.

Interventions: None.

Measurements and main results: The exposure of interest was prehospital serum $25(\mathrm{OH}) \mathrm{D}$ categorised as $\leq 10 \mathrm{ng} / \mathrm{mL}, 11-19.9 \mathrm{ng} / \mathrm{mL}, 20-29.9 \mathrm{ng} / \mathrm{mL}$ and $\geq 30 \mathrm{ng} / \mathrm{mL}$. The primary outcome was acute respiratory failure excluding congestive heart failure determined by International Classification of Diseases Ninth Edition (ICD-9) coding and validated against the Berlin Definition of acute respiratory sistress syndrome. Association between $25(\mathrm{OH}) \mathrm{D}$ and acute respiratory failure was assessed using logistic regression, while adjusting for age, race, sex, Deyo-Charlson Index and patient type (medical vs surgical).

In the cohort, the mean age was 63 years, $45 \%$ were male and $80 \%$ were white; $25(\mathrm{OH}) \mathrm{D}$ was $\leq 10 \mathrm{ng} / \mathrm{mL}$ in $8 \%$ of patients, $11-19.9 \mathrm{ng} / \mathrm{mL}$ in $24 \%, 20-29.9 \mathrm{ng} / \mathrm{mL}$ in $24 \%$ and $\geq 30 \mathrm{ng} / \mathrm{mL}$ in $44 \%$ of patients. Eighteen per cent $(n=351)$ were diagnosed with acute respiratory failure. Compared to patients with $25(\mathrm{OH}) \mathrm{D} \geq 30 \mathrm{ng} / \mathrm{mL}$, patients with lower $25(\mathrm{OH}) \mathrm{D}$ levels had significantly higher adjusted odds of acute respiratory failure ( $\leq 10 \mathrm{ng} / \mathrm{mL}, \mathrm{OR}=1.84(95 \% \mathrm{Cl} 1.22$ to 2.77$)$; $11-19.9 \mathrm{ng} / \mathrm{mL}, \mathrm{OR}=1.60$ (95\% Cl 1.19 to 2.15$)$; 20-29.9 ng/mL, OR=1.37 (95\% Cl 1.01 to 1.86)). Conclusions: Prehospital 25(OH)D was associated with the risk of acute respiratory failure in our critically ill patient cohort.

\section{INTRODUCTION}

In the USA, every year, 190600 patients develop acute respiratory distress syndrome

\section{KEY MESSAGES}

Vitamin D deficiency prior to hospitalization is associated with development of acute respiratory failure.

- Vitamin D deficient patients who develop acute respiratory failure have heightened mortality.

(ARDS), with 74500 associated deaths and 2.2 million days in the intensive care unit (ICU). ${ }^{1}$ Incidences of ARDS among patients with acute illness and mechanically ventilated patients are $7 \%$ and $11-23 \%$, respectively. ${ }^{2}$ Although critical care outcomes in general and those associated with acute respiratory failure have improved over time, long-term outcomes of ICU survivors has gained prominence. $^{3} 4$ Among the more than 100000 patients who survive ARDS each year, many develop cognitive abnormalities, depression, post-traumatic stress disorders and have poor health-related quality of life. ${ }^{15}$

Recent evidence suggests that vitamin $\mathrm{D}$ is a key regulator of the innate and adaptive immune system. ${ }^{5}$ Serum 25-hydroxyvitamin D $(25(\mathrm{OH}) \mathrm{D})$ is the major circulating metabolite of vitamin $\mathrm{D}$, the standard measure of vitamin $\mathrm{D}$ status and is used to assess therapeutic response to supplementation. Low serum 25(OH)D levels are associated with increased risk of viral and bacterial infections as well as sepsis possibly due to effects on innate and adaptive immunity. ${ }^{6} 7$ Additionally, vitamin $\mathrm{D}$ modulates inflammation, fibrosis and airway destruction in the lung which are major steps in ARDS pathogenesis. ${ }^{8} 9$ Further, decreased muscle strength and mass is associated with vitamin $\mathrm{D}$ deficiency. ${ }^{10}$ Recent data from a randomised controlled 
trial on high-dose vitamin $\mathrm{D}$ in critically ill patients (VITdAL-ICU trial) shows as a secondary outcome the improved survival in patients with severe vitamin $\mathrm{D}$ deficiency $(25(\mathrm{OH}) \mathrm{D} \leq 12 \mathrm{ng} / \mathrm{mL})$ who receive vitamin $\mathrm{D} .{ }^{11}$ Data are lacking with regards to the association of prehospitalisation vitamin $\mathrm{D}$ inadequacy and incident ARDS during critical illness.

Given that vitamin $\mathrm{D}$ inadequacy, defined by measuring circulating $25(\mathrm{OH}) \mathrm{D}_{3}$ levels, is increasingly prevalent in the general population of the USA and associated with critical care outcomes, we performed a two-centre observational study of adult patients among whom $25(\mathrm{OH}) \mathrm{D}$ concentrations had been measured for routine clinical reasons within 1 year before hospitalisation. ${ }^{7}{ }^{12-23}$ The objective of this study was to test the hypothesis that vitamin D status before hospital admission is inversely associated with the risk of developing acute respiratory failure in a critically-ill patient cohort.

\section{MATERIALS AND METHODS}

Data on all patients admitted to two teaching hospitals in Boston between 4 August 1998 and 12 January 2011 were obtained through a computerised registry. During the study period, there were 79927 patient ICU admissions to the hospitals under study. Approval for the study was granted by the Partners Human Research Committee (Institutional Review Board). Requirement for consent was waived as the data were analysed anonymously. The cohort included patients $\geq 18$ years of age who received critical care and had serum $25(\mathrm{OH}) \mathrm{D}$ measured between 7 and 365 days before hospitalisation. We excluded patients with congestive heart failure (International Classification of Diseases Ninth Edition (ICD-9) 428.0428.9) diagnosed following hospital admission. ${ }^{24}$ The exposure of interest was serum $25(\mathrm{OH}) \mathrm{D}$ level obtained 7 to 365 days prior to the date of hospital admission and categorised as $25(\mathrm{OH}) \mathrm{D}<10 \mathrm{ng} / \mathrm{mL} ; 10-19.9 \mathrm{ng} / \mathrm{mL}$; $20-29.9 \mathrm{ng} / \mathrm{mL}$ and $\geq 30 \mathrm{ng} / \mathrm{mL} .{ }^{14}$ We define prehospital serum $25(\mathrm{OH}) \mathrm{D}$ concentration $<20 \mathrm{ng} / \mathrm{mL}$ as vitamin $\mathrm{D}$ inadequacy, as suggested by a recent Institute of Medicine report. ${ }^{25}$ In cases where a patient had serum 25 $(\mathrm{OH}) \mathrm{D}$ measured more than once in the year prior to hospitalisation, the serum $25(\mathrm{OH}) \mathrm{D}$ measured closest to the date of hospital admission was utilised.

Race was either self-determined or designated by a patient representative/healthcare proxy. Patient admission 'type' was defined as 'medical' or 'surgical' and incorporates the Diagnostic-Related Grouping (DRG) methodology. ${ }^{26}$ We utilised the Deyo-Charlson Index to assess the burden of chronic illness which is well studied and validated. ${ }^{27}$ Sepsis was defined by the presence of any of the following ICD-9-clinical modification (CM) codes 038.0$038.9,020.0,790.7,117.9,112.5$ or $112.81^{28}, 3$ days prior to critical care initiation to 7 days after critical care initiation, a definition validated in our administrative data. ${ }^{7}$ To determine neighbourhood socioeconomic disadvantage we used geocoded residential address data ${ }^{29}$ from electronic health records; we then linked the zip +4 data to the Area Deprivation Index developed by Singh $e t a \hat{l}^{30}$ and linked to the 2000 US census by Kind et al. ${ }^{31}$

During the study period between 1998 and 2011, the chemiluminescence assay, the radioimmunoassay or liquid chromatography-mass spectroscopy (LC-MS) were employed at different times as a $25(\mathrm{OH}) \mathrm{D}$ assay method. Dates, times and type of $25(\mathrm{OH}) \mathrm{D}$ assay were recorded. The $25(\mathrm{OH}) \mathrm{D}$ assays were tested for imprecision by the clinical laboratories at the two hospitals. Imprecision testing with human serum specimens showed within-run coefficients of variation (CVs) of $\leq 4.5 \%$ for the chemiluminescence assay, $\leq 10.8 \%$ for the radioimmunoassay, and $\leq 8.6 \%$ for LC-MS.

The primary end point was acute respiratory failure defined by Cooke $e t a l^{24}$ and identified by the presence of ICD-9, codes for respiratory failure or pulmonary oedema (518.4, 518.5, 518.81 and 518.82) and mechanical ventilation $(96.7 \times)$, excluding congestive heart failure (428.0-428.9) following hospital admission. ${ }^{24}$ Inclusion of mechanical ventilation codes and the exclusion of heart failure codes increases the specificity of the ICD-9 code combination for ARDS. ${ }^{32}$ In subanalyses, the acute respiratory failure end point was validated against the Berlin Definition of ARDS. ${ }^{33}$ The secondary end point was 90-day all-cause mortality obtained from the Social Security Administration Death Master File. One hundred per cent of the cohort had at least 90-day follow-up. The censoring date was 5 January 2012.

\section{Power calculations and statistical analysis}

In the cohort under study, the incidence of acute respiratory failure was $18 \%$. By assuming acute respiratory failure incidence in patients with prehospital serum $25(\mathrm{OH}) \mathrm{D}>30 \mathrm{ng} / \mathrm{mL}$ to be $18 \%$ and an OR of 1.5 for incident acute respiratory failure in patients with prehospital serum $25(\mathrm{OH}) \mathrm{D} \leq 30 \mathrm{ng} / \mathrm{mL}$, we needed 359 patients with $25(\mathrm{OH}) \mathrm{D}>30 \mathrm{ng} / \mathrm{mL}$ and 359 patients with $25(\mathrm{OH}) \mathrm{D} \leq 30 \mathrm{ng} / \mathrm{mL}$ to achieve $80 \%$ power and $5 \%$ significance.

Unadjusted associations between vitamin $\mathrm{D}$ groups and outcomes were estimated by bivariable logistic regression analysis. Adjusted ORs were estimated by multivariable logistic regression models with inclusion of covariate terms chosen based on the biological plausibility of possible confounding of the vitamin $\mathrm{D}$-acute respiratory failure association. For the primary model, specification of each continuous covariate was adjudicated by the empiric association with the primary outcome using Akaike's Information Criterion; the overall model fit was assessed using the Hosmer Lemeshow test. Models for secondary analyses (90-day mortality) were specified identically to the primary model in order to achieve greatest analogy. Sensitivity analysis were performed for patients with $25(\mathrm{OH}) \mathrm{D}$ measured at various time points prior to hospital admission. Locally weighted scatter plot smoothing (LOWESS) was used to graphically represent the relationship between prehospital $25(\mathrm{OH}) \mathrm{D}$ concentration 
and rate of acute respiratory failure. A multivariable Cox's proportional hazards model was used to illustrate the survival among patients with acute respiratory failure as vitamin $\mathrm{D}$ intake increases. All $\mathrm{p}$ values presented are two-tailed; values below 0.05 were considered to be significant. All analyses are performed using STATA 12.0MP (College Station, Texas, USA).

To validate the accuracy of ICD-9-CM and current procedural terminology (CPT)-defined acute respiratory failure assignment in our study, 206 of the 1985 cohort patients were chosen at random. Subject charts were retrospectively reviewed by two clinician investigators blinded to the subject 25(OH)D level and ICD-9-CM/ CPT acute respiratory failure code assignment to determine if patients had clinical criteria for ARDS in the first 14 days of an ICU admission according to the Berlin definition: (1) acute respiratory failure not fully explained by cardiac failure or fluid overload, per the intensivist of record; (2) bilateral opacities consistent with pulmonary oedema on the chest radiograph or the CT scan; and (3) onset within 1 week after a known clinical insult or new or worsening respiratory symptoms. ${ }^{33}$ The validation criteria were met if the criteria for mild, moderate or severe ARDS, as defined by The Berlin Definition of ARDS, were achieved in the first 14 days of an ICU admission: mild if $\mathrm{PaO}_{2} / \mathrm{FiO}_{2}=201-300 \mathrm{~mm} \mathrm{Hg}$, moderate if $\mathrm{PaO}_{2} / \mathrm{FiO}_{2}=101-200 \mathrm{~mm} \mathrm{Hg}$ and severe if $\mathrm{PaO}_{2} / \mathrm{FiO}_{2} \leq 100 \mathrm{~mm} \mathrm{Hg}$ with PEEP level $\geq 5 \mathrm{~cm} \mathrm{H}_{2} \mathrm{O}$ was present in all ARDS cases. Diagnosis of ARDS was established by consensus of the two clinician investigators and resolved by a third in case of discrepancies.

\section{RESULTS}

Table 1 shows demographic characteristics of the parent ICU cohort and the study cohort. Differences between the parent and study cohorts included gender, patient type and comorbidity. In the study cohort $(\mathrm{N}=1985)$, most patients were women, white and had medicalrelated DRG with a mean age of 63 years. The mean (SD) $25(\mathrm{OH}) \mathrm{D}$ in the study cohort was 29.0 (15.5) ng/ $\mathrm{mL}$ which did not statistically differ by season of $25(\mathrm{OH})$ $\mathrm{D}$ draw $\left(\mathrm{p}=0.12, \chi^{2}\right)$. The majority of $25(\mathrm{OH}) \mathrm{D}$ measurements in the study cohort occurred within 6 months of hospital admission (20\% within 1 month, $48 \%$ within 3 months and $72 \%$ within 6 months). Most study cohort patients had $25(\mathrm{OH}) \mathrm{D}$ levels $\geq 20 \mathrm{ng} / \mathrm{mL}$ ( $8 \%$ with 25 $(\mathrm{OH}) \mathrm{D}<10 \mathrm{ng} / \mathrm{mL} ; 24 \%$ with $10-19.9 \mathrm{ng} / \mathrm{mL} ; 24 \%$ with $20-29.9 \mathrm{ng} / \mathrm{mL}$ and $44 \%$ with $\geq 30 \mathrm{ng} / \mathrm{mL}$ ). The 90 -day mortality of the study cohort was $15.7 \%$.

In the study cohort, the most common Major Diagnostic Codes in the cohort by system were circulatory $31.7 \%$, digestive $14 \%$, musculoskeletal $8.9 \%$, kidney $8.4 \%$, endocrine $7.7 \%$, respiratory $4.8 \%$, injuries $4.4 \%$ and infectious $4.2 \%$. The mean (SD) time from hospital admission to acute respiratory failure diagnosis was 1.46 (4.43) days and the mean (SD) time from hospital admission to ICU admission was 1.90 (6.19) days. Validation of ICD-9-CM/CPT-defined acute respiratory failure assignment, as per the Berlin Definition of ARDS, showed that ICD-9-CM/CPT-defined acute respiratory failure assignment had a sensitivity of $59.4 \%$ (95\% CI 46.4 to $71.5 \%$ ), a specificity of $95.1 \%$ (95\% CI 90.1 to $97.9 \%$ ), a positive predictive value of $84.4 \%$

\section{Table 1 Characteristics of total ICU cohort $(\mathrm{N}=77927)$ and study cohort $(\mathrm{N}=1985)$}

\begin{tabular}{|c|c|c|}
\hline $\mathbf{N}$ & $\begin{array}{l}\text { Total ICU cohort } \\
79927\end{array}$ & $\begin{array}{l}\text { Study cohort } \\
1985\end{array}$ \\
\hline Age-mean(SD) & $61.8(18.3)$ & $63.2(16.2)$ \\
\hline \multicolumn{3}{|l|}{ Sex number (\%) } \\
\hline Female & $33556(42)$ & $1083(55)$ \\
\hline Male & $46371(58)$ & $902(45)$ \\
\hline \multicolumn{3}{|l|}{ Race number (\%) } \\
\hline White & $63712(80)$ & $1602(81)$ \\
\hline Non-white & $16215(20)$ & $383(19)$ \\
\hline \multicolumn{3}{|l|}{ Patient type number (\%) } \\
\hline Medical & 39355 (49) & $1372(69)$ \\
\hline Surgical & $40572(51)$ & $613(31)$ \\
\hline \multicolumn{3}{|l|}{ Deyo-charlson index number (\%) } \\
\hline $0-3$ & $56312(70)$ & $1227(62)$ \\
\hline $4-6$ & $19060(24)$ & $553(28)$ \\
\hline$>6$ & $4555(6)$ & $205(10)$ \\
\hline Body mass index-mean(SD) ${ }^{\star}$ & $27.3(6.9)$ & $27.3(7.7)$ \\
\hline Area deprivation index-mean(SD) $\dagger$ & $86.0(32.8)$ & $81.8(30.4)$ \\
\hline Sepsis number (\%) & $10215(13)$ & $231(12)$ \\
\hline Acute respiratory failure number (\%) & $12308(15)$ & $351(18)$ \\
\hline 90-day mortality number (\%) & 13860 (17) & 311 (16) \\
\hline $\begin{array}{l}\text { Greater Area Deprivation Index means a } \\
{ }^{*} 5527 \text { of the total ICU cohort and } 435 \text { stu } \\
\text { †Area Deprivation Index is an ecological } r \\
\text { ICU, intensive care unit. }\end{array}$ & $\begin{array}{l}\text { Iss index determined. } \\
\text { dvantage. }\end{array}$ & \\
\hline
\end{tabular}


Table 2 Patient characteristics by prehospital vitamin D status

\begin{tabular}{|c|c|c|c|c|c|c|}
\hline \multirow[b]{2}{*}{$\mathbf{N}$} & \multicolumn{5}{|c|}{ Prehospital 25(OH)D, ng/mL } & \multirow[b]{2}{*}{ p Value } \\
\hline & $\begin{array}{l}<10.0 \\
164\end{array}$ & $\begin{array}{l}10-19.9 \\
477\end{array}$ & $\begin{array}{l}20-29.9 \\
473\end{array}$ & $\begin{array}{l}\geq 30 \\
871\end{array}$ & $\begin{array}{l}\text { Total } \\
1985\end{array}$ & \\
\hline Age-mean (SD) & $57.3(16.9)$ & $61.3(16.6)$ & $62.4(15.9)$ & $65.9(15.4)$ & $63.2(16.2)$ & $0.001^{*}$ \\
\hline Sex number (\%) & & & & & & 0.01 \\
\hline Female & $83(51)$ & $243(51)$ & $246(52)$ & $511(59)$ & $1083(55)$ & \\
\hline Male & $81(49)$ & $234(49)$ & $227(48)$ & $360(41)$ & $902(45)$ & \\
\hline Race number (\%) & & & & & & $<0.0001$ \\
\hline White & $125(76)$ & $366(77)$ & $371(78)$ & $740(85)$ & $1602(81)$ & \\
\hline Non-white & $39(24)$ & $111(23)$ & $102(22)$ & 39 (15) & 383 (19) & \\
\hline African-American & $17(10)$ & $43(9)$ & $34(7)$ & $34(4)$ & $128(6)$ & \\
\hline Patient type number (\%) & & & & & & 0.27 \\
\hline Medical & $115(70)$ & $343(72)$ & $331(70)$ & $583(67)$ & $1372(69)$ & \\
\hline Surgical & $49(30)$ & $134(28)$ & $142(30)$ & $288(33)$ & $613(31)$ & \\
\hline Deyo-Charlson index number (\%) & & & & & & 0.087 \\
\hline $0-3$ & $88(54)$ & $285(60)$ & $294(62)$ & $560(64)$ & $1227(62)$ & \\
\hline $4-6$ & $59(36)$ & $135(28)$ & $137(29)$ & $222(25)$ & $553(28)$ & \\
\hline$>6$ & $17(10)$ & $57(12)$ & $42(9)$ & $89(10)$ & $205(10)$ & \\
\hline Diabetes mellitus number (\%) & $49(30)$ & $193(40)$ & $159(34)$ & $274(31)$ & $675(34)$ & 0.005 \\
\hline Body mass index-mean (SD)† & $27.9(8.2)$ & $28.1(9.9)$ & $28.0(6.5)$ & $25.9(5.9)$ & $27.3(7.7)$ & $0.064^{*}$ \\
\hline Season of $25(\mathrm{OH}) \mathrm{D}$ draw number $(\%)$ & & & & & & 0.18 \\
\hline Spring & $43(26)$ & $132(28)$ & $141(30)$ & $242(28)$ & $558(28)$ & \\
\hline Summer & $35(21)$ & $114(24)$ & $120(25)$ & $229(26)$ & $498(25)$ & \\
\hline Winter & $38(23)$ & $119(25)$ & $103(22)$ & $162(19)$ & $422(21)$ & \\
\hline Fall & $48(29)$ & $112(23)$ & $109(23)$ & $238(27)$ & $507(26)$ & \\
\hline Calcium $\geq 10.5$ mg/dL number (\%) & $26(16)$ & $66(14)$ & 60 (13) & $74(9)$ & $226(11)$ & 0.003 \\
\hline Haematocrit $<30 \%$ number (\%) & 31 (19) & $98(21)$ & $88(19)$ & $121(14)$ & $338(17)$ & 0.009 \\
\hline $\begin{array}{l}>90 \text { days between } 25(\mathrm{OH}) \mathrm{D} \text { and Admission } \\
\text { number }(\%)\end{array}$ & $56(34)$ & $192(40)$ & $264(56)$ & $516(59)$ & $1028(52)$ & $<0.001$ \\
\hline Area deprivation index-mean (SD) & $87.1(28.1)$ & $84.6(27.1)$ & $84.1(28.3)$ & $77.9(33.2)$ & $81.8(30.4)$ & $<0.001^{*}$ \\
\hline Sepsis number (\%) & $28(17)$ & $73(15)$ & $53(11)$ & $77(9)$ & $231(12)$ & 0.001 \\
\hline Sputum culture positivity number (\%) & $30(21)$ & $92(22)$ & $71(17)$ & $119(15)$ & $312(17)$ & 0.01 \\
\hline Acute respiratory failure number (\%) & $41(25)$ & $102(21)$ & 89 (19) & $119(14)$ & $351(18)$ & $<0.001$ \\
\hline 90-day mortality number (\%) & $34(21)$ & $111(23)$ & $76(16)$ & $90(10)$ & $311(16)$ & $<0.001$ \\
\hline
\end{tabular}

(95\% CI 69.9 to 93.0$)$ and a negative predictive value of $83.9 \%$ (95\% CI 77.0 to 89.0$)$.

Patient characteristics of the study cohort were stratified according to preadmission vitamin D groups (table 2). Factors that significantly differed between stratified groups included age, gender, calcium and haematocrit. Factors that did not significantly differ between stratified groups included Deyo-Charlson index, patient type (surgical vs medical) and season of $25(\mathrm{OH})$ $\mathrm{D}$ measurement. Table 3 indicates that age, gender and $25(\mathrm{OH}) \mathrm{D}$ are significant predictors of acute respiratory failure in our model.

\section{Primary outcome}

Preadmission 25(OH)D was strongly associated with acute respiratory failure during hospitalisation (table 4). The odds of acute respiratory failure was 2.1-fold, 1.7-fold and 1.5-fold higher in patients with $25(\mathrm{OH}) \mathrm{D}$ values in the $<10 \mathrm{ng} / \mathrm{mL}, 10-19.9 \mathrm{ng} / \mathrm{mL}, 20-29.9 \mathrm{ng} /$ $\mathrm{mL}$ groups, respectively, compared to those with 25
$(\mathrm{OH}) \mathrm{D} \geq 30 \mathrm{ng} / \mathrm{mL} .25(\mathrm{OH}) \mathrm{D}$ in the cohort remains a significant predictor of odds of acute respiratory failure following adjustment for age, race, sex, Deyo-Charlson Index and patient type (medical vs surgical). The adjusted odds of acute respiratory failure was 1.8-fold, 1.6-fold and 1.4-fold higher in patients with $25(\mathrm{OH}) \mathrm{D}$ values in the $<10 \mathrm{ng} / \mathrm{mL}, 10-19.9 \mathrm{ng} / \mathrm{mL}, 20-29.9 \mathrm{ng} /$ $\mathrm{mL}$ groups, respectively, compared to those with 25 $(\mathrm{OH}) \mathrm{D} \geq 30 \mathrm{ng} / \mathrm{mL}$ (table 4$)$. LOWESS plot (figure 1) showed a near inverse linear association between vitamin $\mathrm{D}$ status and an acute respiratory failure rate for $25(\mathrm{OH}) \mathrm{D}$ concentrations of approximately $40 \mathrm{ng} / \mathrm{mL}$; beyond $40 \mathrm{ng} / \mathrm{mL}$, the association appears flat.

Individually running the adjusted model with and without terms for assay, year, season or sepsis did not materially affect the acute respiratory failure estimates reported above (see online supplementary table S1); thus, the vitamin D-acute respiratory failure relationship was not materially confounded by these covariates. Further, utilising $25(\mathrm{OH}) \mathrm{D}$ as a continuous variable, we 
Table 3 Multivariable-adjusted associations between covariates and acute respiratory failure

\begin{tabular}{|c|c|c|c|c|c|c|}
\hline & $\begin{array}{l}\text { Acute respiratory } \\
\text { failure Absent* } \\
1634\end{array}$ & $\begin{array}{l}\text { Acute respiratory } \\
\text { failure Present* } \\
352\end{array}$ & p Value† & OR‡ & $95 \% \mathrm{Cl}$ & p Value \\
\hline Age (per 1 year) & $64(16)$ & $59(17)$ & $<0.001$ & 0.99 & 0.98 to 0.99 & $<0.001$ \\
\hline Sex & & & 0.002 & & & \\
\hline Male & 716 & 186 & & 1.37 & 1.09 to 1.74 & 0.008 \\
\hline Female & 918 & 165 & & 1 & Referent & \\
\hline Race & & & 0.22 & & & \\
\hline Non-white & 307 (19) & $76(22)$ & & 1.10 & 0.82 to 1.47 & 0.53 \\
\hline White & $1327(81)$ & $275(78)$ & & 1 & Referent & \\
\hline Patient type & & & 0.14 & & & \\
\hline Surgical & $493(70)$ & $120(66)$ & & 1.22 & 0.95 to 1.57 & 0.11 \\
\hline Medical & $1141(30)$ & $231(34)$ & & 1 & Referent & \\
\hline Deyo-Charlson index & & & 0.012 & & & \\
\hline $0-3$ & $1034(63)$ & $193(55)$ & & 1 & Referent & \\
\hline $4-6$ & 435 (27) & $118(34)$ & & 1.45 & 1.13 to 1.88 & 0.004 \\
\hline$\geq 6$ & $165(10)$ & $40(11)$ & & 1.30 & 0.89 to 1.90 & 0.18 \\
\hline $25(\mathrm{OH}) \mathrm{D} \S$ & & & $<0.001$ & & & \\
\hline$<10 \mathrm{ng} / \mathrm{mL}$ & $123(8)$ & $41(12)$ & & 1.84 & 1.22 to 2.77 & 0.004 \\
\hline $10-19.9 \mathrm{ng} / \mathrm{mL}$ & 375 (23) & $102(29)$ & & 1.60 & 1.19 to 2.15 & 0.002 \\
\hline $20-29.9 \mathrm{ng} / \mathrm{mL}$ & $384(24)$ & 89 (25) & & 1.37 & 1.01 to 1.86 & 0.04 \\
\hline$\geq 30 \mathrm{ng} / \mathrm{mL}$ & 752 (46) & 119 (34) & & 1.00 & Referent & \\
\hline
\end{tabular}

find that for every increase in preadmission $25(\mathrm{OH}) \mathrm{D}$ of $5 \mathrm{ng} / \mathrm{mL}$, the odds of acute respiratory failure during hospitalisation decreases by $8 \%$ (OR $0.92,95 \%$ CI 0.88 to $0.96 ; \mathrm{p}<0.001)$ when adjusted for age, gender, race, type and Deyo-Charlson index.

We also performed a sensitivity analysis of the timing of prehospital $25(\mathrm{OH}) \mathrm{D}$ draw date. Sensitivity analysis of the effects of excluding patients with preadmission 25 $(\mathrm{OH}) \mathrm{D}$ levels obtained $\geq 30, \geq 60, \geq 90$ or $\geq 180$ days prior to admission did not materially change the association between vitamin D and ICD-9-CM defined acute

Table 4 Unadjusted and adjusted associations between prehospital 25(OH)D level and acute respiratory failure

\begin{tabular}{llll} 
& OR & 95\% Cl & p Value \\
\hline $\begin{array}{l}\text { Unadjusted } \\
\text { 25(OH)D }\end{array}$ & & & \\
$\quad<10 \mathrm{ng} / \mathrm{mL}$ & 2.11 & 1.41 to 3.15 & $<0.0001$ \\
$\begin{array}{l}10-19.9 \mathrm{ng} / \mathrm{mL} \\
20-29.9 \mathrm{ng} / \mathrm{mL}\end{array}$ & 1.72 & 1.28 to 2.30 & $<0.0001$ \\
& 1.46 & 1.08 to 1.98 & 0.01 \\
$\begin{array}{l}\text { Adjusted } \\
\text { 25(OH)D }\end{array}$ & 1.00 & Referent & \\
$\quad<10 \mathrm{ng} / \mathrm{mL}$ & & & \\
$10-19.9 \mathrm{ng} / \mathrm{mL}$ & 1.60 & 1.19 to 2.15 & 0.002 \\
$20-29.9 \mathrm{ng} / \mathrm{mL}$ & 1.37 & 1.01 to 1.86 & 0.04 \\
$\geq 30 \mathrm{ng} / \mathrm{mL}$ & 1.00 & Referent & \\
\hline
\end{tabular}

$\mathrm{Cl}$, OR for acute respiratory failure.

Referent in each case is $25(\mathrm{OH}) \mathrm{D} \geq 30 \mathrm{ng} / \mathrm{mL}$.

Estimates adjusted for age, race, sex, Deyo-Charlson Index and patient type (medical vs surgical). respiratory failure (see online supplementary table S2). A modest attenuation of the effect size was observed as the time difference increased, but the vitamin $\mathrm{D}$ acute respiratory failure associations retained statistical significance.

In cohort patients with acute respiratory failure $(n=381)$, vitamin D status was associated with risk of mortality. Though limited by sample size, patients with

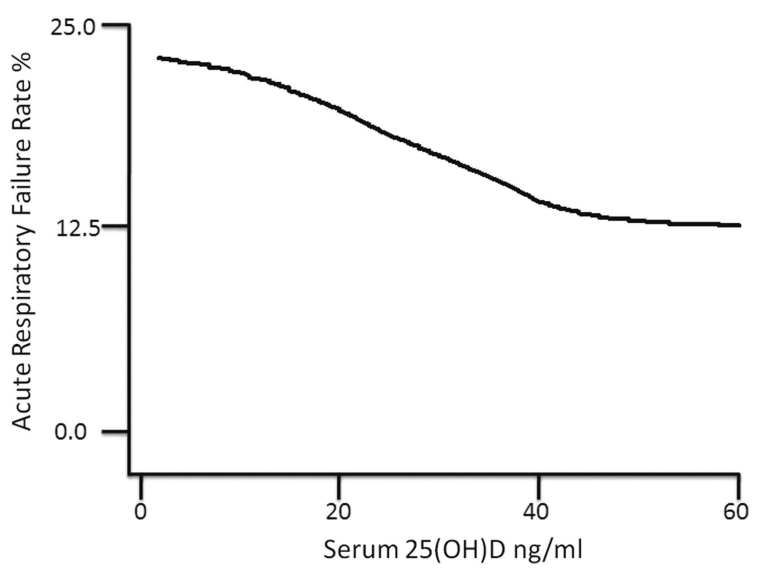

Figure 1 Vitamin D status versus acute respiratory failure Rate. $25(\mathrm{OH}) \mathrm{D}=25$-hydroxyvitamin $\mathrm{D}$. Locally weighted scatter plot smoothing (LOWESS) utilised to represent the near inverse linear association between prehospital 25(OH)D concentration and acute respiratory failure rate. With bandwidth parameter $=0.99,1919$ cohort patients were utilised to construct the curve. 
prehospital $25(\mathrm{OH}) \mathrm{D}$ values of $<10 \mathrm{ng} / \mathrm{mL}, \quad 10-$ $19.9 \mathrm{ng} / \mathrm{mL}$ and $20-29.9 \mathrm{ng} / \mathrm{mL}$ had odds of 90 -day mortality of 2.02 (95\% CI 0.96 to $4.27 ; \mathrm{p}=0.064$ ), 2.57 (95\% CI 1.49 to $4.45 ; \mathrm{p}<0.001)$ and 1.57 (95\% CI 0.89 to $2.80 ; \mathrm{p}=0.12)$, respectively, compared to those with 25 $(\mathrm{OH}) \mathrm{D} \geq 30 \mathrm{ng} / \mathrm{mL}$ following adjustments for age, race, sex, Deyo-Charlson Index and patient type (medical vs surgical; table 5). Cox proportional-hazards regression analysis demonstrated that in patients with acute respiratory failure, the risk of death declines with each $5 \mathrm{ng}$ / $\mathrm{mL}$ increase in prehospital $25(\mathrm{OH}) \mathrm{D}$ adjusted for age, race, sex, Deyo-Charlson Index and patient type (medical vs surgical; HR $0.92,95 \%$ CI 0.87 to 0.97 ; $\mathrm{p}=0.004$ ).

\section{Effect modification}

Analyses based on fully-adjusted models were performed to evaluate the $25(\mathrm{OH}) \mathrm{D}$-acute respiratory failure association, and $\mathrm{p}$ for interaction was determined to explore for any evidence of effect modification. We individually tested for effect modification by hospital, time between $25(\mathrm{OH}) \mathrm{D}$ draw and hospital admission and season of 25 $(\mathrm{OH}) \mathrm{D}$ draw by adding an interaction term to the multivariate models. Effect modification analysis showed that the association between $25(\mathrm{OH}) \mathrm{D}$ and acute respiratory failure was not modified by the hospital that provided care ( $p$ interaction $=0.19)$, or the time between $25(\mathrm{OH})$ $\mathrm{D}$ draw and hospital admission ( $\mathrm{p}$ interaction $=0.30$ ). When we investigated effect modification by season of $25(\mathrm{OH}) \mathrm{D}$ draw, we identified a nearly statistically significant interaction term for $25(\mathrm{OH}) \mathrm{D}$ and acute respiratory failure ( $\mathrm{p}$ interaction $=0.07)$. When the cohort is analysed by restricting this to the season of $25(\mathrm{OH}) \mathrm{D}$ draw, the directionality of the association between 25 $(\mathrm{OH}) \mathrm{D}$ and acute respiratory failure remains, but the effect size is strongest with $25(\mathrm{OH}) \mathrm{D}$ drawn in the spring season and weakest in the fall.

Table 5 Unadjusted and adjusted associations between prehospital 25(OH)D level and 90-day mortality in patients with acute respiratory failure

\begin{tabular}{llll}
\hline & OR & 95\% Cl & p Value \\
\hline $\begin{array}{l}\text { Unadjusted } \\
\text { 25(OH)D }\end{array}$ & & & \\
$<20 \mathrm{ng} / \mathrm{mL}$ & 2.19 & 1.31 to 3.63 & 0.003 \\
$20-29.9 \mathrm{ng} / \mathrm{mL}$ & 1.37 & $\begin{array}{l}0.77 \text { to } 2.44 \\
\text { Referent }\end{array}$ & 0.285 \\
$\geq 30 \mathrm{ng} / \mathrm{mL}$ & 1.00 & & \\
Adjusted & & & \\
$25(\mathrm{OH}) \mathrm{D}$ & & & \\
$<20 \mathrm{ng} / \mathrm{mL}$ & 2.48 & 1.45 to 4.25 & 0.001 \\
$20-29.9 \mathrm{ng} / \mathrm{mL}$ & 1.48 & 0.82 to 2.70 & 0.195 \\
$\geq 30 \mathrm{ng} / \mathrm{mL}$ & 1.00 & Referent & \\
\hline
\end{tabular}

$\mathrm{Cl}$, OR for 90 -day mortality. $\mathrm{N}=381,90$-day mortality $39.9 \%$. Referent in each case is $25(\mathrm{OH}) \mathrm{D} \geq 30 \mathrm{ng} / \mathrm{mL}$.

$<20 \mathrm{ng} / \mathrm{mL}$ cut point chosen for power issues. Estimates adjusted for age, race, sex, Deyo-Charlson Index and patient type (medical vs surgical). $100 \%$ of the cohort had vital status follow-up at 90 days.

\section{DISCUSSION}

The present, two-centre study aimed to determine whether suboptimal vitamin D status prior to hospital admission was associated with acute respiratory failure in the critically ill. In unadjusted and adjusted analyses, we found increased odds of acute respiratory failure in patients with preadmission $25(\mathrm{OH}) \mathrm{D}<20 \mathrm{ng} / \mathrm{mL}$. In addition, our mortality analysis suggests that patients with $25(\mathrm{OH})$ D levels $<20 \mathrm{ng} / \mathrm{mL}$ before hospital admission who develop acute respiratory failure have a higher risk for mortality compared to patients with prehospital $25(\mathrm{OH})$ D levels $\geq 30 \mathrm{ng} / \mathrm{mL}$.

ARDS is due to diffuse alveolar damage mediated by inflammatory cytokines such as tumour-necrosis factor, interleukin (IL)-1, IL-6 and IL-8 and subsequent neutrophil recruitment and release of oxygen free radicals that damage capillary endothelium and alveolar epithelium. ${ }^{34} 35$ Immunomodulatory and proinflammatory associations of vitamin D deficiency are well known. Vitamin D induces expression of the gene for cathelicidin, which promotes intracellular killing of bacteria. ${ }^{36}$ In the lung, cathelicidin likely plays a role in mucosal defence as it is produced by neutrophils, macrophages and airway epithelium, and upregulated in response to infection and inflammation. ${ }^{37}$ These biological observations indicate the potential importance of vitamin D status to innate immunity and ARDS.

Prior studies have reported robust associations of low vitamin $\mathrm{D}$ and sepsis, bloodstream infections and mortality in critically ill adults. ${ }^{13}$ The VITdAL-ICU trial secondary outcome data shows high-dose vitamin D supplementation reduces mortality in patients with severe vitamin $\mathrm{D}$ deficiency $(25(\mathrm{OH}) \mathrm{D} \leq 12 \mathrm{ng} / \mathrm{mL})$, but was not designed to study respiratory outcomes. ${ }^{11}$ In the current study, the reason for an increase in mortality in acute respiratory failure patients with vitamin $\mathrm{D}$ inadequacy is likely to be multifactorial. Other issues that may be important for critical illness outcomes include vitamin $\mathrm{D}$ related effects on vascular endothelial growth factor, endothelin and the renin-angiotensin-aldosterone system. $^{38-40}$ Further, comorbidities including incident hypertension, glucose intolerance, the metabolic syndrome, obesity and cardiovascular disease are all associated with low $25(\mathrm{OH}) \mathrm{D}$ and higher mortality. ${ }^{41-45}$

The present study is not without potential limitations. Observational studies may be limited by bias, confounding, and/or reverse causation. ${ }^{46}$ Importantly, causality cannot be determined in our study. Our utilisation of ICD-9 and CPT coding likely reflects the measured incidence of acute respiratory failure in the cohort rather than the actual incidence. Ascertainment bias may exist in our study as the patient cohort under study had vitamin D status measurements for reasons that may be absent in other critically ill patients. Despite adjustment for multiple potential confounders, residual confounding may contribute to the observed differences in outcomes and vitamin D status could simply be a marker of baseline healthy behaviours. Specifically, we are unable 
to adjust for immobilisation, excessive alcohol intake, smoking status, genetic factors, hypertension, low-density lipoprotein-cholesterol, education level and low milk consumption all of which can alter $25(\mathrm{OH}) \mathrm{D} .{ }^{47} 48$ The percentage of cohort patients who are female is $55 \%$ while the percentage of African-Americans is only $6 \%$, which may limit generalisability. The $25(\mathrm{OH}) \mathrm{D}$-mortality association appears to be preserved when $25(\mathrm{OH}) \mathrm{D}$ is obtained within 30 days of admission. Despite this observation, vitamin $\mathrm{D}$ levels at the time of hospitalisation may be different from the levels when prehospital values were drawn. We also do not have any information as to why $25(\mathrm{OH}) \mathrm{D}$ concentrations were obtained in the cohort. Finally, our observations may represent a healthy user effect rather than causality. ${ }^{49}$

The present study has several strengths. To the best of our knowledge, our study is the first large sample study to evaluate an association between prehospital vitamin D and incident acute respiratory failure. Crucially, we have sufficient statistical power to detect a clinically relevant difference in acute respiratory failure between the vitamin D groups. The exclusion of ICD-9 codes related to heart failure and requirement of mechanical ventilation ICD-9 codes for our exposure increases the specificity of the codes for ARDS. ${ }^{24}$ The Deyo-Charlson Index allowed us to account for chronic medical comorbidities. Finally, by measuring vitamin $\mathrm{D}$ status at least 7 days prior to hospitalisation, we attempted to uncouple the influence of acute illness and inflammation on $25(\mathrm{OH})$ D levels.

\section{CONCLUSION}

In summary, prehospital vitamin D inadequacy $(25(\mathrm{OH})$ $\mathrm{D}<20 \mathrm{ng} / \mathrm{mL}$ ) is associated with incident acute respiratory failure during critical illness and death in patients with acute respiratory failure. Despite our observations, supplementation of vitamin D in critically ill patients cannot be advocated for prevention or treatment of acute respiratory failure as our study does not establish causation. The data presented in combination with the hypothesis generating VITdAL-ICU trial data ${ }^{11}$ does provide an impetus to perform randomised controlled trials to determine whether vitamin D supplementation therapy might have benefit in decreasing the incidence of or improving outcomes of ARDS in critically ill patients with low $25(\mathrm{OH}) \mathrm{D}$.

\section{Author affiliations}

${ }^{1}$ School of Clinical and Experimental Medicine, College of Medical and Dental Sciences, University of Birmingham, Birmingham, UK

${ }^{2}$ Department of Medicine, Hokubu Prefectural Hospital, Nago City, Japan

${ }^{3}$ Channing Division of Network Medicine and Pulmonary and Critical Care Division, Department of Medicine, Brigham and Women's Hospital, Boston, Massachusetts, USA

${ }^{4}$ Division of Endocrinology and Metabolism, Department of Internal Medicine, Medical University of Graz, Graz, Austria

${ }^{5}$ Department of Anesthesia, Critical Care and Pain Medicine, Massachusetts General Hospital, Boston, Massachusetts, USA

${ }^{6}$ Department of Medicine, Brigham and Women's Hospital, Boston,

Massachusetts, USA
${ }^{7}$ Department of Nutrition, Brigham and Women's Hospital, Boston,

Massachusetts, USA

${ }^{8}$ Division of Pulmonary Sciences and Critical Care Medicine, University of Colorado, Denver, Colorado, USA

${ }^{9}$ Division of Pulmonary and Critical Care Medicine, Department of Medicine,

Massachusetts General Hospital, Boston, Massachusetts, USA

${ }^{10}$ Department of Emergency Medicine, Massachusetts General Hospital, Boston, Massachusetts, USA

${ }^{11}$ Departments of Nutrition and Epidemiology, Harvard School of Public Health, Boston, Massachusetts, USA

${ }^{12}$ The Nathan E. Hellman Memorial Laboratory, Renal Division, Brigham and Women's Hospital, Boston, Massachusetts, USA

Acknowledgements This manuscript is dedicated to the memory of our dear friend and colleague Nathan Edward Hellman, MD, PhD. The authors thank Shawn Murphy and Henry Chueh and the Partners HealthCare Research Patient Data Registry group for facilitating use of their database.

Contributors DRT and KBC designed research. DRT, TM and KBC conducted research. KBC, KMM and FKG provided essential materials. KBC performed statistical analysis. DRT, TM, AAL, KA, SAQ, KAL-S, KMM, SWP, FKG, CAC, $\mathrm{Jr}$, EG and KBC wrote the paper. KBC had primary responsibility for final content. All authors read and approved the final manuscript.

Competing interests None declared.

Ethics approval Partners HealthCare Human Research Committee (Institutional Review Board)

Provenance and peer review Not commissioned; externally peer reviewed. Data sharing statement No additional data are available.

Open Access This is an Open Access article distributed in accordance with the terms of the Creative Commons Attribution (CC BY 4.0) license, which permits others to distribute, remix, adapt and build upon this work, for commercial use, provided the original work is properly cited. See: http:// creativecommons.org/licenses/by/4.0/

\section{REFERENCES}

1. Rubenfeld GD, Caldwell E, Peabody E, et al. Incidence and outcomes of acute lung injury. N Engl J Med 2005;353:1685-93.

2. Vincent JL, Sakr Y, Ranieri VM. Epidemiology and outcome of acute respiratory failure in intensive care unit patients. Crit Care Med 2003;31(4 Suppl):S296-9.

3. Lee CM, Fan E. ICU-acquired weakness: what is preventing its rehabilitation in critically ill patients? BMC Med 2012;10:115.

4. Stefan MS, Shieh MS, Pekow PS, et al. Epidemiology and outcomes of acute respiratory failure in the United States, 2001 to 2009 : a national survey. J Hosp Med 2013;8:76-82.

5. Adams JS, Hewison M. Unexpected actions of vitamin D: new perspectives on the regulation of innate and adaptive immunity. Nat Clin Pract Endocrinol Metab 2008;4:80-90.

6. Quraishi SA, Litonjua AA, Moromizato T, et al. Association between prehospital vitamin D status and hospital-acquired bloodstream infections. Am J Clin Nutr 2013:98:952-9.

7. Moromizato $T$, Litonjua $A A$, Braun $A B$, et al. Association of low serum 25-hydroxyvitamin $D$ levels and sepsis in the critically ill. Crit Care Med 2014;42:97-107.

8. Liu X, Nelson A, Wang X, et al. Vitamin D modulates prostaglandin E2 synthesis and degradation in human lung fibroblasts. $\mathrm{Am} \mathrm{J}$ Respir Cell Mol Biol 2014;50:40-50.

9. Dancer RCA, Parekh D, Lax S, et al. Vitamin D deficiency contributes directly to acute respiratory distress syndrome. Thorax Published Online First: 22 Apr 2015. doi:10.1136/thoraxjnl-2014206680

10. Girgis CM, Clifton-Bligh RJ, Hamrick MW, et al. The roles of vitamin $\mathrm{D}$ in skeletal muscle: form, function, and metabolism. Endocr Rev 2013;34:33-83.

11. Amrein K, Schnedl C, Holl A, et al. Effect of high-dose vitamin D3 on hospital length of stay in critically ill patients with vitamin $D$ deficiency: the VITdAL-ICU randomized clinical trial. JAMA 2014;312:1520-30.

12. Ginde AA, Liu MC, Camargo CA Jr. Demographic differences and trends of vitamin D insufficiency in the US population, 1988-2004. Arch Intern Med 2009;169:626-32. 
13. Braun A, Chang D, Mahadevappa K, et al. Association of low serum 25-hydroxyvitamin D levels and mortality in the critically ill*. Crit Care Med 2011;39:671-7.

14. Braun AB, Gibbons FK, Litonjua AA, et al. Low serum 25-hydroxyvitamin $D$ at critical care initiation is associated with increased mortality*. Crit Care Med 2012;40:63-72.

15. Braun AB, Litonjua AA, Moromizato $T$, et al. Association of low serum 25-hydroxyvitamin $D$ levels and acute kidney injury in the critically ill. Crit Care Med 2012;40:3170-9.

16. Quraishi SA, Bittner EA, Blum L, et al. Prospective study of vitamin $D$ status at initiation of care in critically ill surgical patients and risk of 90-day mortality. Crit Care Med 2014;42:1365-71.

17. Ginde AA, Camargo CA Jr., Shapiro NI. Vitamin D insufficiency and sepsis severity in emergency department patients with suspected infection. Acad Emerg Med 2011;18:551-4.

18. Venkatram $S$, Chilimuri $S$, Adrish $M$, et al. Vitamin $D$ deficiency is associated with mortality in the medical intensive care unit. Crit Care 2011;15:R292.

19. McKinney JD, Bailey BA, Garrett LH, et al. Relationship between vitamin D status and ICU outcomes in veterans. J Am Med Dir Assoc 2011;12:208-11.

20. Matthews LR, Ahmed Y, Wilson KL, et al. Worsening severity of vitamin $D$ deficiency is associated with increased length of stay, surgical intensive care unit cost, and mortality rate in surgical intensive care unit patients. Am J Surg 2012;204:37-43.

21. Arnson Y, Gringauz I, Itzhaky D, et al. Vitamin D deficiency is associated with poor outcomes and increased mortality in severely ill patients. QJM 2012;105:633-9.

22. Lee $P$, Eisman JA, Center JR. Vitamin D deficiency in critically ill patients. N Engl J Med 2009;360:1912-14.

23. Amrein K, Zajic P, Schnedl C, et al. Vitamin D status and its association with season, hospital and sepsis mortality in critical illness. Crit Care 2014;18:R47.

24. Cooke CR, Erickson SE, Eisner MD, et al. Trends in the incidence of noncardiogenic acute respiratory failure: the role of race. Crit Care Med 2012;40:1532-8.

25. Ross AC, Manson JE, Abrams SA, et al. The 2011 report on dietary reference intakes for calcium and vitamin $D$ from the Institute of Medicine: what clinicians need to know. J Clin Endocrinol Metab 2011;96:53-8.

26. Rapoport J, Gehlbach S, Lemeshow S, et al. Resource utilization among intensive care patients. Managed care vs traditional insurance. Arch Intern Med 1992;152:2207-12.

27. Charlson ME, Pompei P, Ales KL, et al. A new method of classifying prognostic comorbidity in longitudinal studies: development and validation. J Chronic Dis 1987;40:373-83.

28. Martin GS, Mannino DM, Eaton S, et al. The epidemiology of sepsis in the United States from 1979 through 2000. N Engl J Med 2003;348:1546-54.

29. Duncan DT, Sharifi M, Melly SJ, et al. Characteristics of walkable built environments and BMI z-scores in children: evidence from a large electronic health record database. Environ Health Perspect 2014;122:1359-65.

30. Singh GK. Area deprivation and widening inequalities in US mortality, 1969-1998. Am J Public Health 2003;93:1137-43.
31. Kind AJ, Jencks S, Brock J, et al. Neighborhood socioeconomic disadvantage and 30-day rehospitalization: a retrospective cohort study. Ann Intern Med 2014;161:765-74.

32. Poulose JT, Cartin-Ceba R, Shoja A, et al. Comparison of International Classification of Disease-Ninth Revision (ICD-9) coding with retrospective case review for the diagnosis of acute respiratory distress syndrome. Am J Respir Crit Care Med. 2009;179:A4660.

33. Force ADT, Ranieri VM, Rubenfeld GD, et al. Acute respiratory distress syndrome: the Berlin Definition. JAMA 2012;307: 2526-33.

34. Parsons PE, Eisner MD, Thompson BT, et al. Lower tidal volume ventilation and plasma cytokine markers of inflammation in patients with acute lung injury. Crit Care Med 2005;33:1-6; discussion 230-2.

35. Piantadosi CA, Schwartz DA. The acute respiratory distress syndrome. Ann Intern Med 2004;141:460-70.

36. Wang TT, Nestel FP, Bourdeau V, et al. Cutting edge: 1,25-dihydroxyvitamin D3 is a direct inducer of antimicrobial peptide gene expression. J Immunol 2004;173:2909-12.

37. Zanetti M. Cathelicidins, multifunctional peptides of the innate immunity. J Leukoc Biol 2004;75:39-48.

38. Cardus A, Parisi E, Gallego C, et al. 1,25-Dihydroxyvitamin D3 stimulates vascular smooth muscle cell proliferation through a VEGF-mediated pathway. Kidney Int 2006;69:1377-84.

39. Wu J, Garami M, Cheng T, et al. 1,25(OH)2 vitamin D3, and retinoic acid antagonize endothelin-stimulated hypertrophy of neonatal rat cardiac myocytes. J Clin Invest 1996;97:1577-88.

40. Forman JP, Williams JS, Fisher ND. Plasma 25-hydroxyvitamin D and regulation of the renin-angiotensin system in humans. Hypertension 2010;55:1283-8.

41. Forman JP, Giovannucci E, Holmes MD, et al. Plasma 25-hydroxyvitamin $\mathrm{D}$ levels and risk of incident hypertension. Hypertension 2007;49:1063-9.

42. Chonchol M, Scragg R. 25-Hydroxyvitamin D, insulin resistance, and kidney function in the Third National Health and Nutrition Examination Survey. Kidney Int 2007;71:134-9.

43. Ford ES, Ajani UA, McGuire LC, et al. Concentrations of serum vitamin $D$ and the metabolic syndrome among U.S. adults. Diabetes care. 2005;28:1228-30

44. Wortsman J, Matsuoka LY, Chen TC, et al. Decreased bioavailability of vitamin D in obesity. Am J Clin Nutr 2000;72:690-3.

45. Anderson JL, May HT, Horne BD, et al. Relation of vitamin D deficiency to cardiovascular risk factors, disease status, and incident events in a general healthcare population. Am J Cardiol 2010;106:963-8.

46. Ho PM, Peterson PN, Masoudi FA. Evaluating the evidence: is there a rigid hierarchy? Circulation 2008;118:1675-84.

47. Wang TJ, Zhang F, Richards JB, et al. Common genetic determinants of vitamin $D$ insufficiency: a genome-wide association study. Lancet 2010;376:180-8.

48. Forrest KY, Stuhldreher WL. Prevalence and correlates of vitamin D deficiency in US adults. Nutr Res 2011;31:48-54

49. Shrank WH, Patrick AR, Brookhart MA. Healthy user and related biases in observational studies of preventive interventions: a primer for physicians. J Gen Intern Med 2011;26:546-50. 